\title{
THE OTTOMAN SIEGE AND ASSAULT OF CONSTANTINOPLE IN 1422 AD: ITS MILITARY AND POLITICALASPECT
}

\author{
Tatyana V. Kushch \\ Ural Federal University, Ekaterinburg, Russian Federation
}

\begin{abstract}
This paper addresses the military and political aspect of the Turkish siege of Constantinople in $1422 \mathrm{AD}$, when the Ottomans gained valuable experience to use it later, in the final battle of 1453 . The research is based on the analysis of fifteenth-century Byzantine historical and rhetorical works. The author of this paper has reconstructed the course of the siege and the main stages of preparation to the decisive assault, has analysed the enemy's military plans, the alignment of forces and tactical ploys of siege warfare, the specificities of Ottoman weaponry, and the sides' actions during the assault. Attention has been paid to the Byzantines' behaviour in the period of military conflict and the emperors' political actions for the conflict resolution. The history of the siege and assault of the Byzantine capital in 1422 has been placed into the political context of the period in question, and has been uncovered as a stage in the development of the Byzantine-Ottoman relations in the late fourteenth and early fifteenth century. The paper concludes that the Ottomans' rout resulted from a series of circumstances: the perfection of the fortification system of Constantinople, total mobilization of the metropolitan population, the lack of maritime blockade, and the rebel in the rear of the Ottomans starting not without a help from the Byzantines, all of this allowed the city to withstand. The siege was relieved; however, the situation in foreign policy was still difficult for Byzantium, thus making the emperor to search for peace with the sultan.
\end{abstract} Murad II.

Key words: military and political history, Late Byzantium, Constantinople, Ottoman sieges, the Palaiologoi,

Citation. Kushch T.V. The Ottoman Siege and Assault of Constantinople in 1422 AD: Its Military and Political Aspect. Vestnik Volgogradskogo gosudarstvennogo universiteta. Seriya 4, Istoriya. Regionovedenie. Mezhdunarodnye otnosheniya [Science Journal of Volgograd State University. History. Area Studies. International Relations], 2017, vol. 22, no. 5, pp. 261-270 (in Russian). DOI: https://doi.org/10.15688/jvolsu4.2017.5.24

\section{ТУРЕЦКАЯ ОСАДА И ШТУРМ КОНСТАНТИНОПОЛЯ 1422 ГОДА: ВОЕННО-ПОЛИТИЧЕСКИЙ АСПЕКТ}

\author{
Татьяна Викторовна Кущ \\ Уральский федеральный университет, г. Екатеринбург, Российская Федерация
}

\begin{abstract}
Аннотация. Статья посвящена военно-политическому аспекту турецкой осады Константинополя 1422 г., в ходе которой османы получили ценный военный опыт, использованный ими затем в решающей схватке 1453 года. Исследование строится на анализе византийских исторических и риторических сочинений XV в. Автор статьи реконструирует ход осады и основные этапы подготовки к решающему штурму, рассматривает военные планы противника, расстановку сил и тактические приемы ведения осадной войны, особенности вооружения турок, действия сторон в период штурма. Внимание уделено также поведению византийцев в период военного противостояния и политическим шагам императоров в поисках разрешения конфликта. История осады и штурма византийской столицы в 1422 г. помещена в политический контекст эпохи и показана как этап развития византийско-турецких отношений в конце XIV-начале XV века. В статье делается вывод о том, что поражение турок было определено рядом обстоятельств: совершенство фортификационной сис() темы Константинополя, всеобщая мобилизация столичного населения, отсутствие морской блокады, начав-
\end{abstract}




\section{ВИЗАНТИЯ И ВОЙНА}

шийся не без помощи византийцев мятеж в тылу турок - все это позволило городу выстоять. Однако, хотя осада и была снята, внешнеполитическая ситуация, остававшаяся сложной для Византии, вынуждала императора искать мир с султаном.

Ключевые слова: военно-политическая история, Поздняя Византия, Константинополь, турецкие осады, Палеологи, Мурад II.

Цитирование. Кущ Т. В. Турецкая осада и штурм Константинополя 1422 года: военно-политический аспект // Вестник Волгоградского государственного университета. Серия 4, История. Регионоведение. Международные отношения. - 2017. - Т. 22, № 5. - С. 261-270. - DOI: https://doi.org/10.15688/jvolsu4.2017.5.24

История османских осад византийской столицы началась задолго до трагических событий 1453 г. Первая осада Константинополя пришлась на время правления византийского императора Мануила II Палеолога (1391-1425). Еще до вступления на престол будущий василевс получил печальный опыт противостояния туркам, осадившим в 1383 г. Фессалонику, которой он тогда управлял в качестве деспота. После неудачной организации обороны второго по значению центра империи ему пришлось бежать, сдав в 1387 г. город на милость победителя [7, p. 151]. К моменту воцарения Мануила II Византия уже находилась в вассальной зависимости от османского султана, и новый император был вынужден участвовать в его военных компаниях в Малой Азии. После разрыва вассальных отношений, последовавшем после встречи христианских правителей с султаном Баязидом I (1389-1402) в Серрах, турки осенью 1394 г. впервые осадили византийскую столицу. Константинополь сумел выстоять благодаря тому, что турецкие войска, окружившие город с суши, не смогли перекрыть морские пути сообщения, по которым в столицу поступало все необходимое для ее жизнеобеспечения [4, p. 123-146, 216; 16, p. 149-183]. Все попытки заручиться военной и финансовой помощью Запада не увенчались успехом. Осада столицы была окончательно снята после разгрома турок войсками Тимура в 1402 г., а начавшаяся следом междоусобная борьба наследников султана позволила византийцам на какое-то время забыть об османской угрозе. Робкая попытка Мусы, одного из турецких претендентов на султанский престол, осадить в 1411 г. Константинополь не представляла большой опасности для ромеев [16, р. 186].

Внешнеполитическая ситуация для Византии коренным образом изменилась с воца- рением султана Мурада II (1421-1451), который уже в 1422 г. осадил Константинополь и Фессалонику (возвращенную византийцам по договору 1403 г.), вторгся на Пелопоннес и опустошил Морейский деспотат. Эти действия стали ответом нового султана византийцам, активно проводившим политику вмешательства во внутренние дела османов [4, p. 355359]. Пытаясь играть на династических амбициях представителей рода Османа, ромейские правители сделали ставку на Мустафу, брата покойного султана Мехмеда I (14131421), но тот потерпел поражение от своего племянника Мурада II. Победитель не простил ромеям поддержки его соперника, отправив карательные экспедиции вглубь византийских владений. Хотя попытка турок овладеть Константинополем в 1422 г., о чем речь пойдет в этой статье, и провалилась, она стала, по сути, генеральной репетицией перед финальной битвой, состоявшейся спустя три десятилетия.

В научной литературе, посвященной поздневизантийскому периоду, событию осады 1422 г. уделяют незаслуженно мало внимания. В работах, рассматривавших политическую историю Византии накануне ее падения, авторы давали лишь общую канву неудачного штурма Мурадом II столицы [4, р. 360-365; 15 , p. 59; 16, p. 187-190; 17, p. 332-333]. Специалисты по военной истории хоть и обращали внимание на тактику и вооружение, использованные в период осады, однако рассматривали их в контексте развития военного дела того времени [5, р. 336-337; 12, р. 168-169, 171-172, 190-192]. Мы постараемся по мере сил восполнить этот пробел, сосредоточив внимание прежде всего на военно-политическом аспекте истории этой осады. Значимость постановки этой проблемы заключается прежде всего в том, что полученный турками под стенами Константинополя в 1422 г. военно- 
политический опыт был во многом учтен ими в решающей схватке 1453 г. [18, p. 494]. Важно и то, что в ходе интересующего нас штурма турки впервые применили технические новшества, в дальнейшем повлиявшие на тактику ведения осадной войны. Кроме того, это столкновение имело политические последствия для Византии - вскоре после этих событий обессиленная империя вынуждена была вновь признать свою вассальную зависимость от султана.

Главным нашим источником станет сочинение Иоанна Канана «Рассказ о войне, случившейся в Константинополе 6930 г., когда Амурат-бей с сильным войском напал на город и почти было овладел им, но Пресвятая Матерь Божия сохранила его» [6]. Этот рассказ, составленный по горячим следам неискушенным писателем, содержит большое количество деталей и подробностей, которые не встретишь в произведениях высокой литературы. Данный источник до сих пор не стал предметом специального изучения [18, p. 494, n. 68]. Его свидетельства дополняют сообщения более поздних историков Дуки, Лаоника Халкокондила и Георгия Сфрандзи. Сведения об осаде, пусть и весьма скупые, содержатся в хрониках XV в. [19, Chr. 9/49, 13/1-4, 22/34, 94 A/5]. Отзвуки тех событий можно встретить также и в риторических сочинениях [13, $\sigma .132$ 199, 200-221]. Опираясь на этот круг источников, восстановим ход тех событий.

Если Канан начинает свое повествование с момента появления турецкого авангарда под стенами Константинополя, то другие источники сообщают и о предыстории тех событий. Осознав серьезность намерений Мурада II в отношении Константинополя, византийцы предприняли попытку смягчить разъяренного султана и дипломатическим путем отвести нависшую угрозу. Согласно Сфрандзи, трое послов-апокрисиариев (Димитрий Кантакузин, Матфей Ласкарис и грамматик Ангел Филоммат) в апреле 1422 г. были направлены в ставку султана с предложением о мире [9, Х. 1], но Мурад II велел заковать дипломатов в цепи и взял их с собой в поход против Константинополя. Вероятно именно этих пленников, не называя по имени, и имел в виду Канан, когда писал следующие строки: «Он (Мурад. - T. К.) привел с собой удерживаемых в железных оковах посланников императора, которых тот отправил обсудить мир и дружбу. Как жестокий и бесчеловечный варвар он приговорил их к оковам и заключению и грозил смертью этим невинным людям, словно они были виновны» [6, p. 60.190-61.195]. Согласно Дуке, незадолго до прибытия турецких отрядов к Константинополю византийцы предприняли еще одну попытку дипломатическим путем уладить конфликт, 8 июня 1422 г. отправив к султану в качестве послов Лахана Палеолога и Марка Ягариса [8, XXVIII, 2]. После провала мирных переговоров и последовала атака византийской столицы.

Осада длилась три месяца - с 10 июня по 6 сентября 1422 года. Историк Георгий Сфранзди, создававший свой труд спустя несколько десятилетий, не совсем точен в датах первого появления турок под Константинополем и штурма города. Он выстраивает хронологию событий следующим образом: «И 8 июня того же года он (Мурад. - T. K.) послал Михалбея и блокировал Константинополь, а в 15-й день того же месяца прибыл и сам Мурад, его господин, и осадил город... И в 22-й день месяца августа он предпринял общий штурм города. И в 6 день месяца сентября 31 года, не добившись, с божьей помощью, успеха он отошел от Константинополя» [9, Х. 1]. Согласно другим источникам, вызывающим больше доверия, турецкие отряды под командованием визиря Михалбея 10 июня подошли к городу, 20 июня к ним присоединился султан Мурад с подкреплением, решающая же атака состоялась 24 августа. Спустя две недели (6 сентября) после провала штурма турецкий султан отвел свои войска [19, Chr. 13/1-4, 22/34]. Канан, отличающийся последовательностью изложения материала и вниманием к деталям, приводит те же даты и указывает даже точное время первого появления турок («в тридцать второй год правления императоров, Мануила Палеолога и его сына Иоанна, в год 6930 (1422), и пятнадцатый год индикта, десятый день месяца июня, третий день недели, второй час дня» [6, p. 54.25-27]) и начала штурма («в год 6930 двадцать четвертого дня августа в понедельник в семь часов» [6, p. 75.555-557]).

Согласно Канану, первая часть войска мусульман, прибывшая к Константинополю, 


\section{ВИЗАНТИЯ И ВОЙНА}

насчитывала около 10 тысяч воинов («дважды по пять тысяч») [6, p. 4]. Подошедшие силы «взяли под свой контроль целый район города и сельской области, что были под императорской властью, лишили нас всего близ города, нанесли ущерб округе, разграбили ее и захватили пленников, одних убили, других переправили в Иконию и Арацапитас

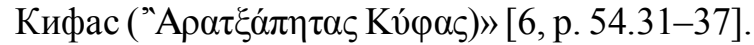
Эта фраза точно описает обычную практику разорения округи легкой конницей (акынджи).

Через десять дней после начала блокады столицы в лагерь противника прибыли новые силы под командованием султана. О численности второй части турецкой армии мы, к сожалению, не знаем, однако Канан неоднократно упоминал об огромных размерах войска, обложивших столицу с суши: турки «господствовали везде от одного конца города у Золотых Ворот до другого у Ксилопорта» [6, p. 65.318-66.320].

Благодаря Канану нам известно множество подробностей военного характера: соотношение военных сил, тактические приемы ведения осадной войны, военные планы противника, осадные сооружения и орудия, использовавшиеся турками. Он проявляет прекрасную осведомленность в организации военного дела противника, а его ремарки («как это заведено», «это обычная практика в осадном деле» $[6$, p. 56.88, 59.143-144]), сопровождающие рассказ, свидетельствуют о знакомстве византийцев с турецкими приемами ведения войны.

После появления османов у византийской столице началась поэтапная подготовка к будущему наступлению. Турки, окружив город, тут же приступили к сооружению одинарного, по всей видимости, земляного, бруствера ( та стрелы от фортификационных укреплений греков [6, p. 56.79-80]. Эта насыпь была «прочной и хорошо укреплена огромными бревнами и прочными досками. Они расположили перед бруствером щит из сплетенных ветвей, чтобы принимать стрелы, выпущенные из луков и арбалетов ромеев, и камни их бомбард. А позади этого бруствера он (султан. - T. К.) определил, чтобы стояли смелые и бесстрашные воины из каждого племени его войска, как это заведено, чтобы защищать бруствер обыч- ным образом, и чтобы они сражались позади него луками и арбалетами и бесчисленными большими и малыми орудиями, которые для этой цели они принесли. Они разместили самые большие орудия, с помощью которых они надеялись проломить стены города и так захватить его, в месте, где был ров, но не подобный другим рвам, а заброшенный и за долгое время заполнившийся землей, и прямо у него была башня, которая пришла в ветхое состояние и имела трещину сверху до низу» [6, p. 56.80-57.100]. Ров, о котором идет речь, тянулся вокруг крепостных стен Константинополя на расстоянии приблизительно 15 м от внешней стены, имел ширину до 20 м, глубину 10 м, был обнесен зубчатой стеной высотой в 1,5 м со стороны города и заполнен водой $[11$, p. 202]. К началу XV в. этот ров находился в заброшенном состоянии, что облегчало задачу неприятелю.

Благодаря Канану мы знаем точное расположение возводимого бруствера. Он тянулся вдоль рва «близ церкви Св. Кириака между воротами Св. Романа и Харисийскими воротами и ближе к реке, именуемой Ликос, чем к ним» [6, p. 57.111-114]. Именно на этом участке стены, известном как «Средняя стена»

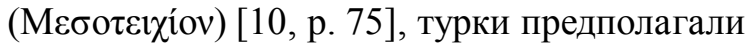
сделать брешь. Выбор направления главного удара определялся прежде всего состоянием фортификационной системы города. Турки, вероятно, обследовав византийский укрепления, остановились именно на этом отрезке, убедившись, что здесь крепостные стены и башни, выстоявшие в период предыдущей осады, особенно обветшали, а ров, давно заброшенный и полузасыпанный, не представлял более препятствия.

За бруствером часть турок начала рыть глубокие траншеи, чтобы под покровом ночи пробираться незамеченными к крепостным стенам и делать под ними подкопы, где они хотели установить бревенчатые подпорки. Этот обычный для ведения осадной войны прием позволил бы в нужный момент подрубить и поджечь деревянные конструкции, чтобы обвалить ослабевшую стену и через образовавшуюся брешь открыть путь в город. Тем временем другой турецкий отряд искал древний водопровод, по которому вода поступала в городские цистерны, в надежде, как 
полагает Канан, по трубам тайно проникнуть в город [6, p. 59.150-155]. Размер труб в некоторых местах, действительно, был достаточен для того, чтобы человек мог спокойно по ним пройти [11, p. 200]. Именно таким способом когда-то проник в город смещенный Юстиниан II [20, p. 522]. Не исключено также, что турки, разыскивая нитку водопровода, не знали о такой его пропускной способности, а намеревались перекрыть подачу воды блокированному населению, что было обычным приемом в осадном деле. Османы, таким образом, действовали по хорошо известному плану подготовки к штурму: подкопы под фортификационными сооружениями, возведение защитной насыпи, перекрытие поставок продовольствия в осажденный город.

Одновременно со строительством насыпи и рытьем подкопов неприятель был занят возведением подвижных деревянных башен «с обитыми железом колесами, и эти башни были такой же высоты, что и городские башни, и они даже возвышались над ними» [6, p. 58.120-122]. Эти башни тащили быки и волы, которых османы пригнали с собой. Наряду с осадными башнями тут же собирались повозки, незаменимые при штурме города. Канан упоминает о нескольких разновидностей повозок, имевшие зооморфные названия:

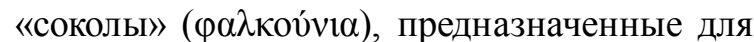
тарана стен; «черепахи» ( $\chi \varepsilon \lambda \omega ́ v \alpha \imath)$ - подвижные навесы, сверху покрытые свежими коровьими шкурами для защиты от огня; «боль-

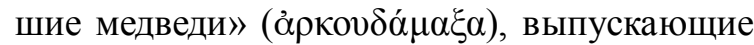
стрелы [5, p. 337; 6, p. 58.126-127].

Мурад привез в обозе «огромное количество самых изобретательно сделанных и самых разрушительных военных машин, с помощью которых он ожидал разрушить часть городской стены» [6, p. 56.67-69]. В арсенале противника были и другие деревянные механизмы, как, к примеру, передвижная «рука»

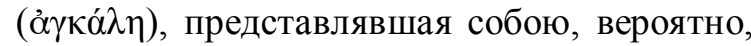
катапульту или метательную машину, а так-

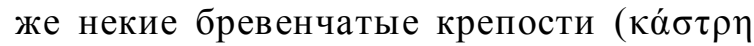
$\xi \tilde{\nu} \lambda \mathrm{iv \alpha )}$ с обитыми железом колесами [6, p. 58.128-134].

Канан, описывая отдельные виды турецкого вооружения, использует термины то из античного военного словаря (бкєvฑ - снаряжение,

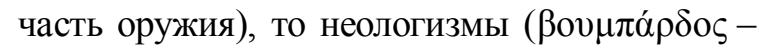

бомбарда), что временами затрудняет их идентификацию. Он нигде не говорит о турецкой артиллерии, однако упоминание о планах турок разрушить часть стены, косвенно указывает на использование пушек. Известно, что стена Феодосия осталась в целом неповрежденной во время осады Баязидом в 1394-1402 гг., несмотря на использование тогда требуше. Но то, что на вооружении осаждавших были пушки, не вызывает сомнения. Согласно Халкокондилу, Мурада сопровождали канониры из Гер-

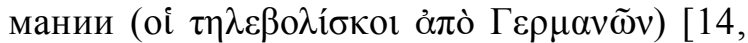
p. 231.16]. Именно во время штурма 1422 г. турки впервые применили артиллерийские орудия [5, p. 337].

Представляет интерес сообщение Канана о том, что султан для пополнения арсенала обложил в период осады подвластное население особым налогом: «каждый двор каждого мужчины, находившийся в империи турок на востоке и западе, дал от 10 до 20 стрел для луков» [6, p. 60.184-187]. Это позволило Мураду создать солидный запас наиболее расходных в условиях боя метательных снарядов («они собрали стрел в таком бессчетном количестве, что мы сперва не поверили сообщению об их числе, до времени, когда началась битва») [6, p. 60.181-183].

Полным ходом шла и мобилизация неприятельских сил. В лагерь противника стекались все новые и новые отряды, откликнувшиеся на призыв султана. Войско противника было полиэтничным и включало «мужчин из бесчисленных племен» [6, p. 66.331-332], в том числе и татар, проявлявших особое рвение в бою [6, p. 66.331-332]. Наряду с воинами в стан турок поспешили явиться многочисленные торговцы, менялы, ремесленники и духовные деятели, желавшие поживиться военной добычей [6, p. 60.168-170]. Каждый из них преследовал свою цель: «воины для грабежа, торговцы для торговли трофеями, в том числе пленниками, и одни желали женщин, другие мужчин, третьи мальчиков, кто-то домашний скот, кто-то домашнюю утварь. Священники считали наших монахинь за дар и трофей как знак щедрости деспота турок» [6, p. 60.171-177].

Видя боевые приготовления турок, ромеи испытывали страх в предвкушении участи, ожидающей их в случае падения города. Горький опыт утраты византийских городов и их 


\section{ВИЗАНТИЯ И ВОЙНА}

разграбления турками давал основания для самых страшных ожиданий. Пророчески Канан рисует незавидную участь соотечественников в случае успеха противника: «Завоевание Великого города и пленение его жителей, насилие над его женщинами, распущенное поведение в отношении целомудренных дев, обрезание мальчиков, разрушение церквей, глумление над святыми ликами, обращение места поклонения величайшему Богу в место, где хвалят Мухаммеда, и жилище демонов и мечеть для Расула и Мухаммеда. И что стало бы более ужасным и худшим, в десять тысяч крат хуже, чем самая страшная смерть, это разрушение святой веры христиан и обращение их в поклоняющихся Мухаммеду» [6, p. 66.344-67.350]. Очевидно, противостояние захватчикам трактовалось жителями города в первую очередь как борьба за свою веру [1, c. 108].

Подготовка к штурму шла и за стенами города. На стенах и башнях постоянно дежурили воины, следя за перемещениями противника и его приготовлениями к атаке. Наряду с ромеями, в обороне города, согласно сообщению Дуки, были задействованы и критские отряды, в обязанности которых входила прежде охрана императорских ворот [8, XXVIII, $1 ; 12$, p. 115]. Император Мануил II в силу возраста и состояния здоровья уже не мог непосредственно руководить обороной города, препоручив это дело старшему сыну и соправителю Иоанну VIII, который, хоть и уступал отцу в военном опыте и стратегическом мышлении, принял на себя эту ответственность. Как отметил Исидор Киевский, Иоанн VIII лично патрулировал по ночам крепостные стены [13, б. 177.26-28], а во время штурма самоотверженно сражался возле ворот Св. Романа [6, p. 67.375]. Сам же Мануил II пытался, опираясь на свой политический опыт, посредством дипломатии и интриг урегулировать ситуацию. Согласно Дуке, старый император сыграл определенную роль в подстрекательстве Мустафы, еще одного претендента на султанский трон, против Мурада II, чтобы отвлечь последнего от осады [8, XXVIII, 6]. Как заметил М. Бартузис, это был несомненный триумф византийской дипломатии [5, p. 117].

Византийцы, все еще верившие в готовность европейских правителей придти на по- мощь грекам в критическую минуту, рассчитывали прежде всего на поддержку итальянцев, чьи торговые интересы также могли пострадать в случае падения города. Пользуясь тем, что Константинополь не был блокирован с моря, византийский император взывал о помощи к итальянским республикам. Однако, как и в предыдущую осаду, его надежды оказались тщетными. Венецианский Сенат 26 августа 1422 г. постановил отказать в немедленной военной и финансовой поддержке осажденному городу и рекомендовал василевсу ромеев обратиться к Генуе и госпитальерам Родоса. Кроме того, венецианцы посоветовали императору заключить мир с Мурадом, в чем они выразили готовность посодействовать [21, № 1855]. Византийцам не приходилось рассчитывать на помощь извне, и они могли полагаться лишь на собственные силы.

Дата штурма была назначена находившимся в турецком лагере суфийским шейхом Мирсаитой, определившим исходя из астрологических расчетов наиболее благоприятное время для схватки. Мурад, готовясь к решающей атаке, отдал приказ привести войска в боевой порядок: «Тут же орды мусульман и все отряды привели в исполнение этот приказ и они распределили оружие между собой всех видов, самые большие военные приспособления и самые совершенные осадные машины. Некоторые воины принесли разные лестницы, малые и большие, другие притащили бревна и балки, кто-то нес горящие факелы ( $\mu \alpha \alpha \lambda \alpha \dot{\alpha} \delta \varepsilon \varsigma)$, другие имели маленькие

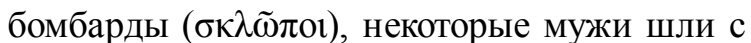
огромными железными орудиями, скифы поднимали вверх колья, называемые серпами ( крепкими, большими и все покрытые железом, и некоторые несли щиты, сплетенные из прутьев, кто-то - прямоугольные щиты $(\pi \alpha \beta \varepsilon ́ \tau \zeta \alpha)$. Они все были защищены крепким железными доспехами и огромными шлемами» [6, p. 65.304-315]. Шеренги турецких войск в боевом порядке выстроились перед стенами. Основная роль на первом этапе отводилась лучникам, которые должны были одновременно пускать стрелы, давая возможность другим отрядам подойти к стенам и взобраться на них [6, p. 66.323-326]. 
Штурм города начался в час пополудни 24 августа 1422 года. Турецкие отряды под звуки барабанов и труб и военные кличи двинулись к стенам Константинополя. С помощью крюков и лестниц одни турки под прикрытием лучников карабкались на стены, другие с помощью таранов, в качестве которых использовали стволы деревьев, старались пробить дыры в стенах, третьи пытались поджечь ворота.

Тем, кто взбирался на стены, ромеи рубили головы, которые, по утверждению Канана, затем отсылали императору [6, p. $71.455-$ 457]. Халкокондил, вероятно, более реалистичен, когда упоминает о том, что греки швыряли отрубленные головы в сторону неприятеля [14, p. 233.7-8]. Проникавших в башни турок также убивали на месте. Особо современник отметил мужество и отвагу византийских женщин, которые не побоялись придти на стены. Кто-то из них сражался наравне с воинами, другие же поддерживали мужчин-защитников, подносили камни, оказывали первую помощь раненым, давали воду и вино страдающим от жажды [6, p. 71.471-72.480].

Оборону города держали не только профессиональные воины. По традиции к защите города были привлечены и отряды самообороны, состоявшие из жителей столицы и округи, самостоятельно обеспечивавшие себя вооружением [5, p. 295]. Канан пишет: «Подобно пчелам из улья, потревоженным дымом, один подгонял другого, так что мужчины из каждого квартала и разного возраста были подняты в городе, и каждый бился с тем оружием, которое смог найти, и порой даже без него, в то время как враги сражались мечами и дубинами. Встречались даже те, кто не был вооружен даже этим, они обвязывали веревку вокруг стола, за которым ели, и крышки от бочек, и прикрывались ими вместо щита. Некоторые мужи пришли на битву без всего этого, они и одними камнями сражались так отважно и смело, словно были вооружены всеми видами оружия» [6, p. 69.423-70.431]. Другие источники сообщают, что даже «монахи храбро сражались вместе с остальными» [13, б. 177.34-178.3].

Битва длилась до заката. Туркам не удалось сломить сопротивление ромеев, и они отступили. Бегство султана с 50 воинами, если верить энкомиасту, переломило исход битвы $[13$, б. 215.31-216.2]. Канан приводит цифры потерь с каждой стороны: более тысячи раненных и убитых у турок, сто раненных и триста убитых у ромеев [6, p. 75.557-561]. Насколько эти данные соответствовали действительности, вопрос открытый, но, как известно, количество жертв среди осаждающих всегда многократно превосходило число погибших защитников. Хронист, оставивший короткую запись о штурме, сообщил о потерях при штурме следующее: «Год 6930, индикт 15, $<24$ августа $>$, день $<2>$, в день святого Евтихия, ученика святого Иоанна Богослова, нечестивый Мурат штурмовал Великий город. Ромеи победили и турки, многие тысячи, были убиты» [19, Chr. 9/49].

Поражение турок было определено рядом обстоятельств. Фортификационная система Константинополя, несмотря на ветхость отдельных участков стены и запущенность оборонительного рва, вновь показала свою действенность. Осадные машины и технические приспособления, тактические уловки султана и отвага турок не дали и на этот раз результата. Артиллерия, впервые примененная при штурме, служила лишь дополнением к традиционным средствам осады. Нужно отдать должное и мужеству защитников города, бесстрашно сражавшихся на крепостных стенах. Свою роль сыграли и всеобщая мобилизация населения, и действия обоих императоров по организации обороны. Провалу осады способствовало и отсутствие у турок флота, способного блокировать Константинополь с моря. Этот опыт, несомненно, будет учтен ими в будущем.

Простояв еще две недели на подступах к городу, Мурад велел снять осаду и 6 сентября 1422 г. увел свои войска в Анатолию. Третья осада византийской столицы была отбита благодаря не только героическим усилиям оборонявшихся, но и, как считали ромеи, заступничеству Богоматери, явившей чудо и защитившей от погибели опекаемый ею город [6, р. 75.561-564]. Причина ухода Мурада II на Восток в действительности крылась во внутренних противоречиях османов. В Анатолии вновь разгоралась новая гражданская война. Попытку поставить под контроль Османское государство предпринял 12-летний 


\section{ВИЗАНТИЯ И ВОЙНА}

брат Мурада II Мустафа, подталкиваемый византийским императором Мануилом II [14, 233.14-17]. И хотя султану удалось позже одержать вверх над Мустафой-младшим, именно эта конфронтация заставила его свернуть осаду Константинополя. Осада была снята, но внешнеполитическая ситуация, остававшаяся сложной для Византии, вынуждала императора искать мира с султаном. В феврале 1424 г. ромеям пришлось заключить договор с османами, взяв на себя обязательство платить им дань и вновь признать свою вассальную зависимость от них [16, p. 35-36].

События того штурма глубоко врезались в память византийцев. Симеон Фессалоникийский спустя несколько лет, обращаясь к жителям Фессалоники, переживавшим долгую турецкую осаду, вспоминал о событиях 1422 г. следующее: «Вы все знаете, что случалось после смерти того нечестивого человека, султана (Мехмеда I. $-T$. K.): как Мустафа победил; как наши люди были слишком пассивны, чтобы воспользоваться преимуществами этого; как генуэзцы стали инструментом возвышения безбожного Мурада и каким ужасным злом это закончилось; как осадили столицу вместе с нашим городом (Фессалоникой. $T$. K.); как внушающая страх армия и сборище безбожников были брошены против благочестивого града Константина; как были установлены осадные машины и начались сражения; при том что натиск и ярость нечестивцев против нас были сильнее, чем когдалибо в прошлом» [3, p. 52.18-23]. Жителей столицы спасло, по мнению епископа, только заступничество высших сил, на которые он увещевал надеяться и своих сограждан.

Когда кастильский идальго Перо Тафур в 1438 г. оказался в Константинополе, местные жители поведали ему и об осаде 1422 г., о чем он упомянул в своих записках [22, p. 111]. Со слов Тафура, византийцы были уверены, что только вмешательство высших сил уберегло тогда город. Воспоминания о тех страшных месяцах обороны города были настолько живы, что ромеи считали важным рассказывать прибывавшим в столицу иностранцам о случившемся полтора десятка лет назад избавлении от турок [2, § 179].

О неудачной попытке Мурада II овладеть городом помнили и незадолго до падения Кон- стантинополя в 1453 году. Однако ситуация в корне изменилась с приходом к власти амбициозного и неукротимого Мехмеда II. Георгий Сфрандзи, получивший известие о воцарении нового султана, произнес слова, оказавшиеся пророческими: «Тот (Мурад II. $-T$. K.) был стар, попытка выступить против Константинополя была им уже совершена, и ничего такого он больше предпринимать не собирался, а желал лишь мира и спокойствия. Этот же, ставший теперь господином, молод и с детства является врагом христиан; он их поносил и грозился учинить что-либо против них... И если Господь допустит, чтобы в нем возобладали молодость и злоба и чтобы он напал на Константинополь, то я не знаю, что будет» [9, ХXX. 4-6]. Действительно, Мехмед II, учтя опыт отца и применив новейшие по тем временам военные приемы, сумеет полностью блокировать город и найти способ разрушить его стены. Дни града Константина были сочтены.

\section{СПИСОК ЛИТЕРАТУРЫ}

1.Кущ, Т. В. Турки под стенами Константинополя (1422): образ врага в восприятии защитников города / Т. В. Кущ // Известия Уральского федерального университета. Серия 2, Гуманитарные науки. 2015. - № 4 (145). - C. 105-115.

2. Тафур, П. Странствия и путешествия / Перо Тафур ; пер., предисл. и коммент. Л. К. Масиеля Санчеса. - М. : Индрик, 2006. -296 c.

3. Balfour, D. Politico-historical Works of Symeon Archbishop of Thessalonica (1416/17 to 1429) / D. Balfour. - Wien : Verlag der Österreichischen Akademie der Wissenschaften, 1979. - $319 \mathrm{p}$.

4. Barker, J. W. Manuel II Palaeologus (13911425): A Study in Late Byzantine Statesmanship / J. W. Barker.-New-Brunswick; New-Jersey : Rutgers University Press, 1969. - $614 \mathrm{p}$.

5. Bartusis, M. C. The Late Byzantine Army. Arms and Society, 1204-1453 / M. C. Bartusis. Philadelphia : University of Pennsylvania Press, 1997. $-438 \mathrm{p}$.

6. Cananos, G. L'assedo di Constantinopoli / Giovanni Cananos ; introduzione, testo critico, traduzione, note e lessico a cura di E. Pinto. - Messina : EDAS, 1977. $-126 \mathrm{p}$.

7. Dennis, G. T. The Reign of Manuel II Palaeologus in Thessalonica, 1382-1387/ G. T. Dennis. Roma: Pont. Institutum Orientalium Studiorum, 1960.$179 \mathrm{p}$. 
8. Ducas. Historia Turco-Byzantina (1341-1462) / ed. V. Grecu. - Bucarest : Editio Academiae Reipublicae Popularis Romanicae, 1958. - 503 p.

9. Georgios Sphrantzes. Memorii, 1401-1477 / ed. V. Grecu. - Bucharest : Editura Academici Republicii Socialiste Románia, 1966. - 618 p.

10. Hanak, W. The Constantinopolitan Mesoteikhion in 1453: Its Topography, Adjacent Structures and Gates / W. Hanak // Byzantine Studies. 1999. - № 4. - P. 69-98.

11. Janin, R. Constantinople byzantine. Développement urbain et répertoire topographique / R. Janin. - Paris : Institut français d'études byzantines, 1950. $-483 \mathrm{p}$.

12. Kyriakidis, S. Warfare in Late Byzantium 1204 1453 / S. Kyriakidis. - Leiden; Boston : Brill, 2011.-257 p.

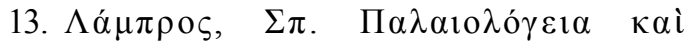

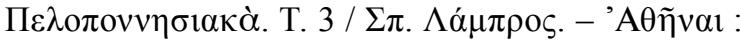

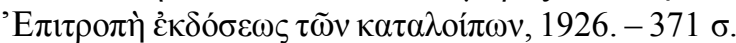

14. Laonici Chalcocondylae Atheniensis Historiarum libri decem / ed. I. Bekker. - Bonn : Impensis ed. Weberi, 1843. $-590 \mathrm{p}$.

15. Le monde byzantin. T. 3. L'Empire grec et ses voisins $\mathrm{XIII}^{\mathrm{e}}-\mathrm{XV}^{\mathrm{e}}$ siècle / ed. A. Laiou, C. Morrisson. Paris : Presses Universitaires de France, 2010. - 494 p.

16. Necipoğlu, N. Byzantium between the Ottomans and the Latins. Politics and Society in the Late Empire / N. Necipoğlu. - Cambridge : Cambridge University Press, 2009. - $350 \mathrm{p}$.

17. Nicol, D. M. The Last Centuries of Byzantium, 1261-1453 / D. M. Nicol. - Cambridge : Cambridge University Press, $1972 .-463 \mathrm{p}$.

18. Philippides, M. The Siege and the Fall of Constantinople in 1453. Historiography, Topography and Military Studies / M. Philippides, W. Hanak. Ashgate : Farnham, 2011.-759 p.

19. Schreiner, P. Die byzantinischen Kleinchroniken (Chronica Byzantina Brevoria). Vol. 1 / P. Schreiner.Wien : Verlag der Österreichischen Akademie der Wissenschaften, 1975. $-688 \mathrm{~s}$.

20. The Chronicle of Theophanes Confessor / ed. by C. Mango et R. Scott. - New York : Clarendon Press, 1997. $-744 \mathrm{p}$.

21. Thiriet, Fr. Régestes des délibérations du Sénat de Venise concernant la Romanie (1329-1379). Vol. 2 / Fr. Thiriet. - Paris : Mouton\&Co, 1959. - 300 p.

22. Vasiliev, A. A. Pero Tafur. A Spanish Traveler of the Fifteenth Century and His Visit to Constantinople, Trebizond and Italy / A. A. Vasiliev // Byzantion. - 1932. - Vol. 7. - P. 111-113.

\section{REFERENCES}

1. Kushch T.V. Turki god stenami Konstantinopolya (1422): obraz vraga v vospriyatii zashchitnikov goroda [Turks under the Walls ofConstantinople(1422): The Image of the Enemy Viewed by the City's Defenders]. Izvestiya Uralskogo federalnogo universiteta. Seria 2. Gumanitarnye nauki, 2015, no. 4 (145), pp. 105-115.

2. Masiel Sanches L.K., ed. Pero Tafur. Stranstviya i puteshestviya [Pero Tafur. Travels and Trips]. Moscow, Indrik Publ., 2006. 296 p.

3. Balfour D. Politico-historical Works of Symeon Archbishop of Thessalonica (1416/17 to 1429). Wien, Verlag der Österreichischen Akademie der Wissenschaften, 1979. $319 \mathrm{p}$.

4. Barker J. W. Manuel II Palaeologus (13911425): A Study in Late Byzantine Statesmanship. NewBrunswick; New-Jersey, Rutgers University Press, 1969. $614 \mathrm{p}$.

5. Bartusis M.C. The Late Byzantine Army. Arms and Society, 1204-1453. Philadelphia, University of Pennsylvania Press, 1997. 438 p.

6. Pinto E., ed. Giovanni Cananos. L'assedo di Constantinopoli. Messina, EDAS, 1977. 126 p.

7. Dennis G.T. The Reign of Manuel II Palaeologus in Thessalonica, 1382-1387. Roma, Pont. Institutum Orientalium Studiorum, 1960. 179 p.

8. Grecu V., ed. Ducas. Historia Turco-Byzantina (1341-1462). Bucarest, Editio Academiae Reipublicae Popularis Romanicae, 1958. 503 p.

9. Grecu V., ed. Georgios Sphrantzes. Memorii, 1401-1477. Bucharest, Editura Academici Republicii Socialiste Románia, 1966. 618 p.

10. Hanak W. The Constantinopolitan Mesoteikhion in 1453: Its Topography, Adjacent Structures and Gates. Byzantine Studies, 1999, no. 4, pp. 69-98.

11. Janin R. Constantinople byzantine. Développement urbain et répertoire topographique. Paris, Institut français d'études byzantines. 1950.483 p.

12. Kyriakidis S.Warfare in Late Byzantium 12041453. Leiden; Boston, Brill, 2011.257 p.

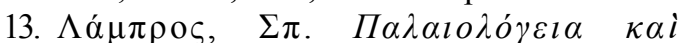
$\Pi \varepsilon \lambda o \pi o v v \eta \sigma \imath \alpha \kappa \dot{\alpha}$. T. 3 [Palaiologeia and

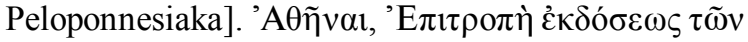

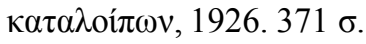

14. Bekker I., ed. Laonici Chalcocondylae Atheniensis Historiarum libri decem. Bonn, Impensis ed. Weberi, 1843. 590 p.

15. Laiou A., Morrisson C., ed. Le monde byzantin. T. 3. L'Empire grec et ses voisins $X I I I^{e}-X V^{e}$ siècle [The Byzantine World. Vol. 3. Greek Empire and its Neighbours]. Paris, Presses Universitaires de France, 2010. 494 p.

16. Necipoğlu N. Byzantium between the Ottomans and the Latins. Politics and Society in the Late Empire. Cambridge, Cambridge University Press, 2009. 350 p.

17. Nicol D.M. The Last Centuries of Byzantium, 1261-1453. Cambridge, Cambridge University Press, $1972.463 \mathrm{p}$.

18. Philippides M., Hanak W. The Siege and the Fall of Constantinople in 1453. Historiography, 


\section{ВИЗАНТИЯ И ВОЙНА}

Topography and Military Studies. Ashgate, Farnham, 2011.759 p.

19. Schreiner P. Die byzantinischen Kleinchroniken (Chronica Byzantina Brevoria). Vol. 1 [The Byzantine Small Chronic]. Wien, Verlag der Österreichischen Akademie der Wissenschaften, 1975. 688 S.

20. Mango C., Scott R., eds. The Chronicle of Theophanes Confessor. New York, Clarendon Press, 1997. $744 \mathrm{p}$.
21. Thiriet Fr. Régestes des délibérations du Sénat de Venise concernant la Romanie (1329_ 1379). Vol. 2 [Regesten of Venice Senat Discussions Concerning Romanie]. Paris, Mouton\&Co, 1959. $300 \mathrm{p}$.

22. Vasiliev A.A. Pero Tafur. A Spanish Traveler of the Fifteenth Century and His Visit to Constantinople, Trebizond and Italy. Byzantion, 1932, vol. 7, pp. 111-113.

\section{Information about the Author}

Tatiana V. Kushch, Doctor of Sciences (History), Associate Professor, Head of Department of Ancient and Medieval History, Ural Federal University, Prosp. Lenina, 51, 620000 Ekaterinburg, Russian Federation, tkushch@yandex.ru, https://orcid.org//0000-0001-9097-5466

\section{Информация об авторе}

Татьяна Викторовна Кущ, доктор исторических наук, доцент, заведующая кафедрой истории Древнего мира и Средних веков, Уральский федеральный университет, просп. Ленина, 51, 620000 г. Екатеринбург, Российская Федерация, tkushch@yandex.ru, https://orcid.org//0000-0001-90975466 